\title{
GIS Application for Climatic Change Prediction Using Stepwise Regression
}

\author{
P.Balamurugan $^{1}$, Dr.A.Ilanthirayan ${ }^{2}$, M.S.Kaviraj ${ }^{3}$, S.Boobathiraja ${ }^{4}$ \\ ${ }^{1 \& 4}$ Assistant Professor, Dept of Civil Engg, Erode Sengunthar Engineering College \\ ${ }^{2}$ Assistant Professor, Dept of Geography, Government Arts College, Karur \\ ${ }^{3}$ Assistant Professor, RVS Technical Campus Faculty of Engineering, Coimbatore
}

\begin{abstract}
Climate change refers to any significant change in the measure of climate lasting for an extended period of time. In other words, climate change includes major changes in temperature, precipitation, or wind patterns, among other effects, that occur over several decades or longer. Climate is the average weather in a given place, usually over a period of more than 30 years. The Earth's climate depends on the balance between the amount of energy received from the sun and the amount of energy that is absorbed or radiated back into space. Natural influences can alter how much heat is reflected or absorbed by the Earth's surface, including changes in the sun's intensity, volcanic eruptions, and multi-year climate cycles such as El Niño. Human activities such as deforestation and the production of greenhouse gases also affect this balance. These alterations, in turn, affect climate on local, regional, and global scales.
\end{abstract}

\section{INTRODUCTION}

Earth's average temperature has risen by $1.4^{\circ} \mathrm{F}$ over the past century, and is projected to rise another 2 to $11.5^{\circ} \mathrm{F}$ over the next hundred years. Small changes in the average temperature of the planet can translate to large and potentially dangerous shifts in climate and weather. The evidence is clear that rising global temperatures have been accompanied by changes in weather and climate. Many places have seen changes in rainfall, resulting in more floods, droughts, or intense rain, as well as more frequent and severe heat waves. However, global warming itself represents only one aspect of climate. Some changes to the climate are unavoidable. Carbon dioxide can stay in the atmosphere for nearly a century, so Earth will continue to warm in the coming decades. The warmer it gets, the greater the risk for more severe changes to the climate and Earth's system. Although it's difficult to predict the exact impacts of climate change, what's clear is that the climate we are accustomed to is no longer a reliable guide for what to expect in the future.

\section{STUDY AREA}

The Cauvery River rises in the Western Ghats and flows in eastwardly direction passing through the states of Karnataka, Tamil Nadu, Kerala and Pondicherry before it drains into Bay of Bengal. The basin lies between latitudes $10^{\circ} 05^{\prime} \mathrm{N}$ and $13^{0} 30^{\prime} \mathrm{N}$ and longitudes $75^{\circ} 30^{\prime} \mathrm{E}$ and $79^{\circ} 45^{\prime} \mathrm{E}$. It is bounded on the west by the Western Ghats, on the east and south by the Eastern Ghats and on the north by the ridges separating it from the Tungabhadra (Krishna) and Pennar basins.

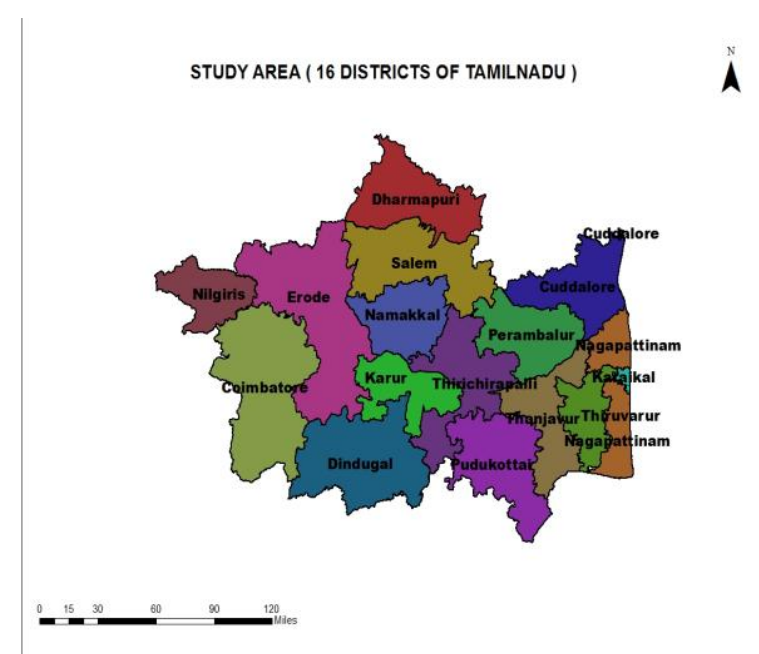

Fig No.2. Study area (Cauvery basin Tamil Nadu) 


\section{SOFTWARE AND DATA USED}

Data pre-processing, preparation and processing methods performed in the study. ESRI ArcGIS and ERDAS IMAGINE 9.2 software. A total of 31 years of data (1972 - 2002) were available for each station. Rainfall Data (1972-2002),Temperature Data(1972-2002), Potential Evapotranspiration(1972-2002), Relative humidity (1972- 2002) \& Wind Speed were collectesd and are standardized.

\section{VARIABLE TREATMENT}

There are three aspects relating to the analysis of the climate data. First it is evident that climate changes non-uniformly throughout a year. Therefore, it is difficult to recreate the original annual series and in order to analyse the long term climate variability a 5-year moving average has been used. Second, climate data usually exhibit obvious seasonality and therefore monthly rather than annual statistical relationships are sought for every unknown dependent variable. Third, the independent and dependent variables are transformed to make them non-dimensional. Supposing that there are $\mathrm{N}$ years of monthly data. They can be defined initially as: monthly average temperature $T\{i, j)$, precipitation $P(i, j)$, net radiation $R(i, J)$, humidity $H(i, J)$, and wind speed $U(i, j)$, where the number of year $i=1,2, \ldots, N$; and the number of month/' $=1,2, \ldots, 12$. Data of $\mathrm{N}$ years is processed with a 5 -year moving average, and $(N-5+1)$ values are produced for each variable

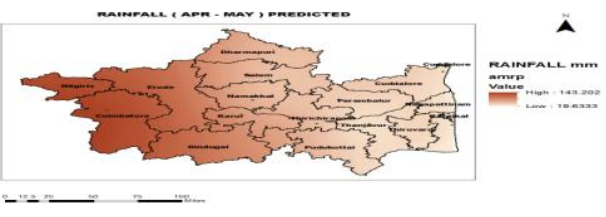

Fig No.4.1 predicted rainfall (Apr-May)

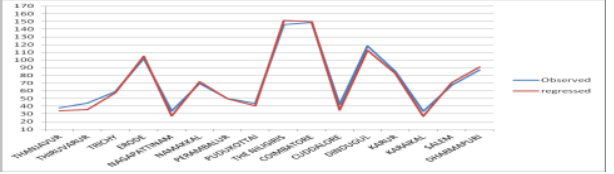

Fig No.4.2 Observed and Predicted rainfall values for 16 stations(Apr-May)

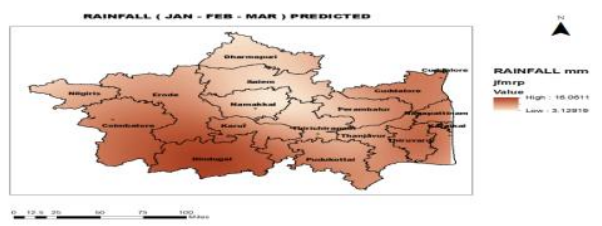

Fig No.4.3 Predicted Rainfall (Jan-Feb-Mar)

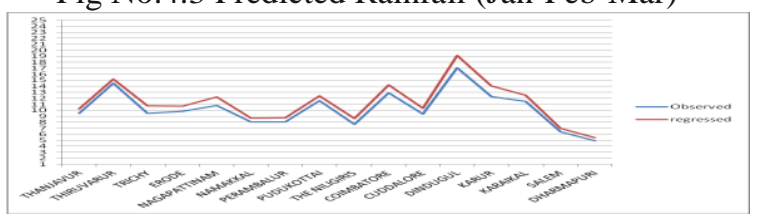

Graf No.4.4 Observed and Predicted rainfall values for 16 stations (Jan-Feb-Mar)

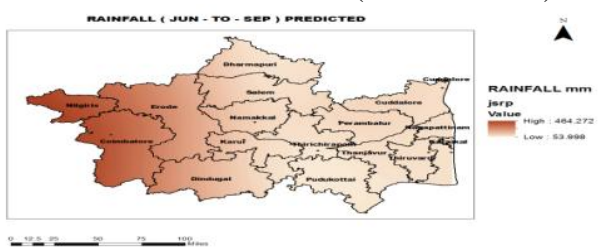

Fig No.4.5 Predicted Rainfall(Jun to Sep)
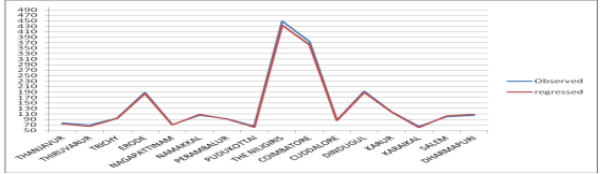

Fig No.4.6 Observed and Predicted rainfall values for 16 stations (Jun to Sep)

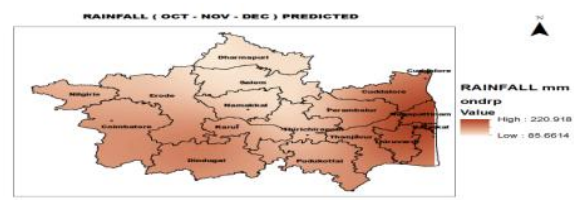

ig No.4.7 Predicted Rainfall(Oct-Nov-Dec)

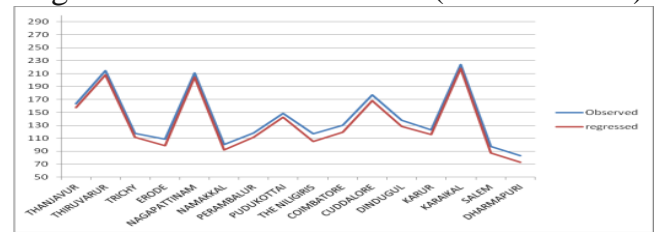

Fig No.4.8 Observed and Predicted rainfall values for 16 stations(Oct-Nov-Dec)

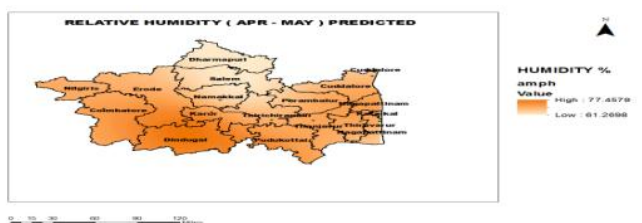

Fig No.4.9c Predicted Humidity(Apr-May)

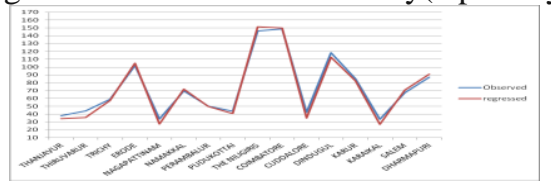

Fig No.4.10 Observed and Predicted humidity values for 16 stations(Apr-May)

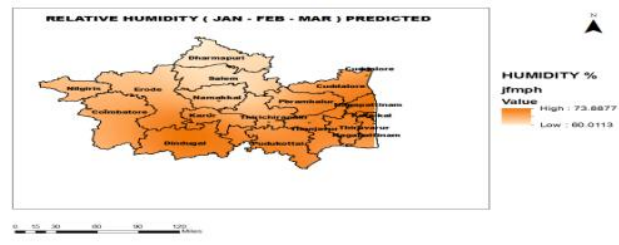

Fig No.4.11c Predicted Humidity(Jan-Feb-Mar)

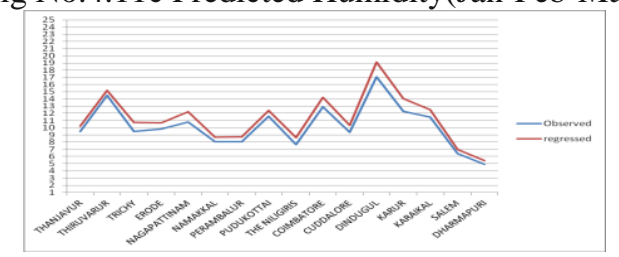


Fig No.4.12 Observed and Predicted humidity values for 16 stations(Jan-Feb-Mar)

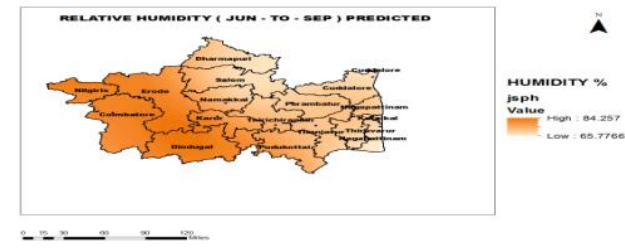

Fig No.4.13c predicted Humidity(Jun to Sep)

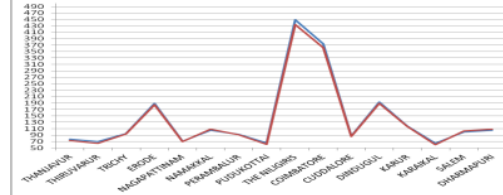

Fig No.4.14 Observed and Predicted humidity values for 16 stations(Jun to Sep)

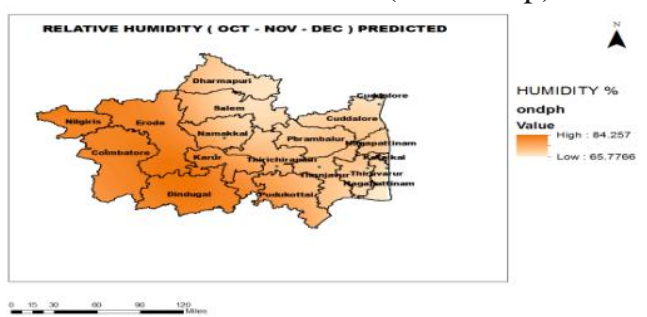

Fig No.4.15c predicted Humidity(Oct-Nov-Dec)

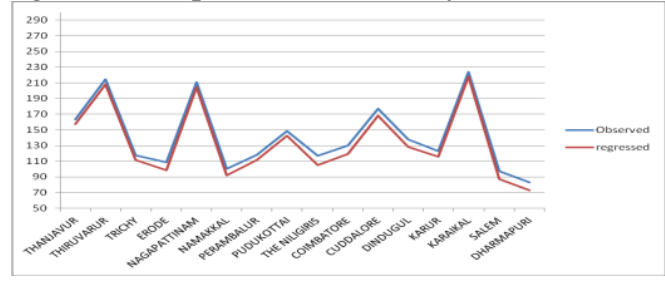

Fig No.4.16 Observed and Predicted humidity values for 16 stations(Oct-Nov-Dec)

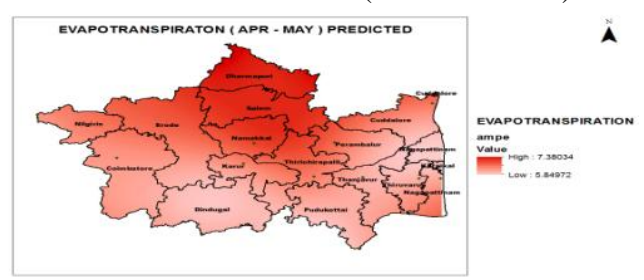

Fig No.4.17c predicted PET(Apr-May)

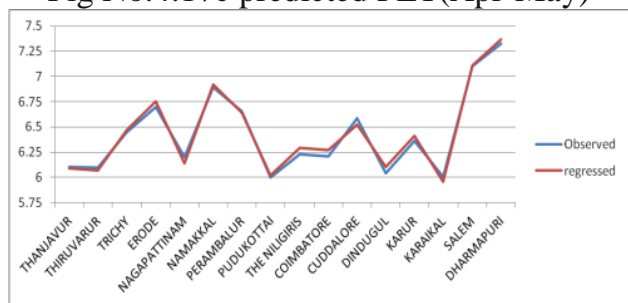

Fig No.4.18 Observed and Predicted PET values for 16 stations (Apr-May)

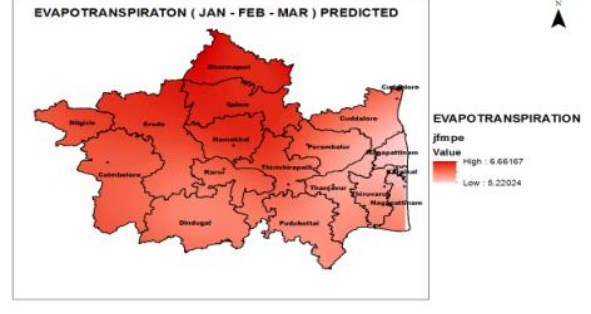

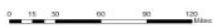

Fig No.4.19c Predicted PET (Jan-Feb-Mar)

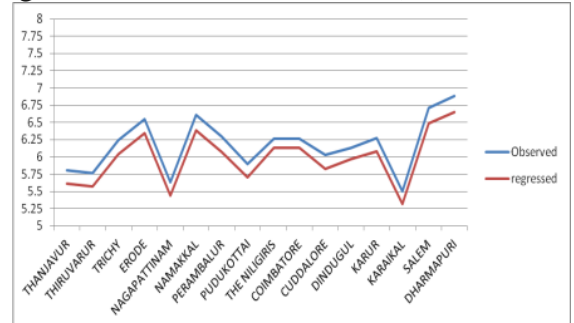

Fig No.4.20 Observed and Predicted PET values for 16 stations(Jan-Feb-Mar)

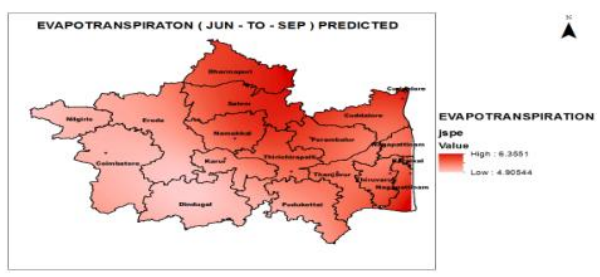

Fig No.4.21c predicted PET(Jun to Sep)

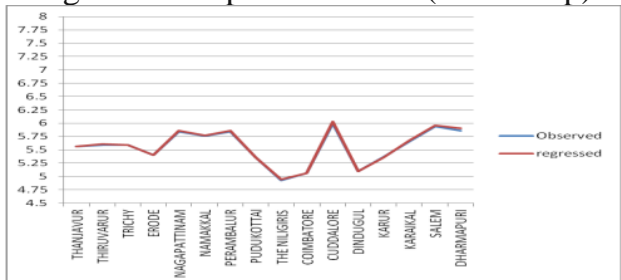

Fig No.4.22 Observed and Predicted PET values for 16 stations(Jun toSep)

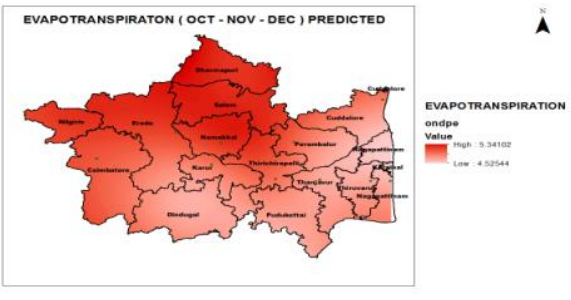

Fig No.4.23c predicted PET(Oct-Nov-Dec)

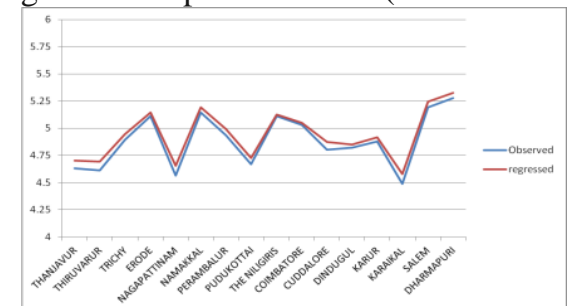

Fig No.4.24 Observed and Predicted PET values for 16 stations (Oct-Nov-Dec) 
V. VALIDATION OF RESULTS

Table No.4.4 validation chart

\begin{tabular}{|c|c|c|c|c|c|c|c|}
\hline STATION & \multirow{2}{*}{ SEASONS } & \multicolumn{2}{|c|}{ TRICHY } & \multicolumn{2}{c|}{ COIMBATORE } & \multicolumn{2}{c|}{ CUDDALORE } \\
\cline { 3 - 8 } & PRE & OBS & PRE & OBS & PRE & OBS \\
\hline \multirow{4}{*}{} & Jan-Feb-Mar & 27.779 & 28 & 27.0389 & 27 & 27.076 & 26.333 \\
\cline { 2 - 8 } & Apr-May & 31.202 & 32.5 & 30.211 & 30.5 & 31.65127 & 31 \\
\cline { 2 - 8 } & Jun to Sep & 29.338 & 30.75 & 27.756 & 27 & 31.4 & 29 \\
\cline { 2 - 8 } & Oct-Nov-Dec & 27.531 & 27 & 26.483 & 25.333 & 28.225 & 26.333 \\
\hline \multirow{3}{*}{$\overline{\bar{N}}$} & Jan-Feb-Mar & 27.905 & 28.333 & 26.237 & 26.333 & 26.2090 & 26.333 \\
\cline { 2 - 8 } & Apr-May & 31.199 & 32 & 28.226 & 28 & 30.745 & 30 \\
\cline { 2 - 8 } & Jun to Sep & 29.207 & 31.25 & 27.71 & 26.25 & 31.3296 & 30 \\
\cline { 2 - 8 } & Oct-Nov-Dec & 27.411 & 27 & 27.432 & 25.333 & 27.14 & 26.333 \\
\hline \multirow{3}{*}{} & Jan-Feb-Mar & 27.841 & 27.667 & 26.135 & 26.333 & 27.177 & 26.667 \\
\cline { 2 - 8 } & Apr-May & 31.006 & 32 & 29.9921 & 29.5 & 31.719 & 31.5 \\
\cline { 2 - 8 } & Jun to Sep & 29.121 & 31 & 27.5795 & 27.25 & 31.2339 & 31 \\
\cline { 2 - 8 } & Oct-Nov-Dec & 27.457 & 27.667 & 27.51 & 25.667 & 28.29 & 27 \\
\hline
\end{tabular}

VI. VISUAL INTERPRETATION OF LST AND NDVI IMAGERY
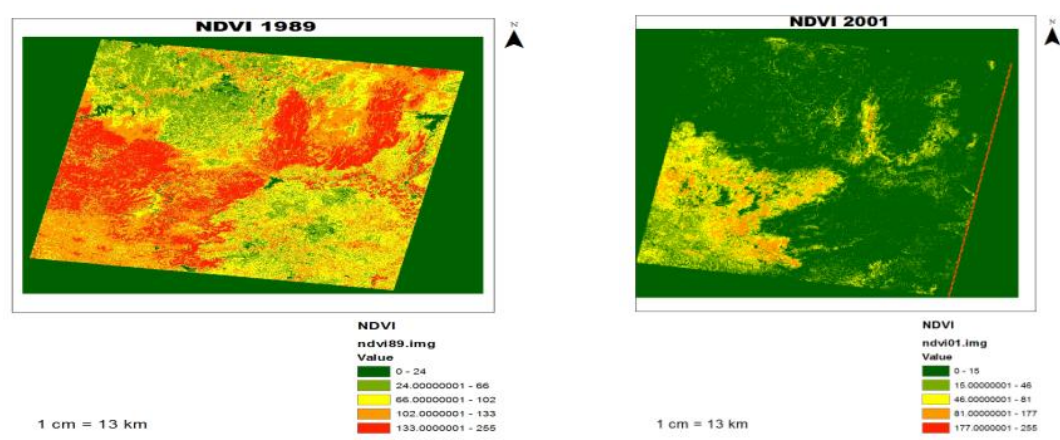

Fig No.4.25 NDVI variation for the year $1989 \& 2001$
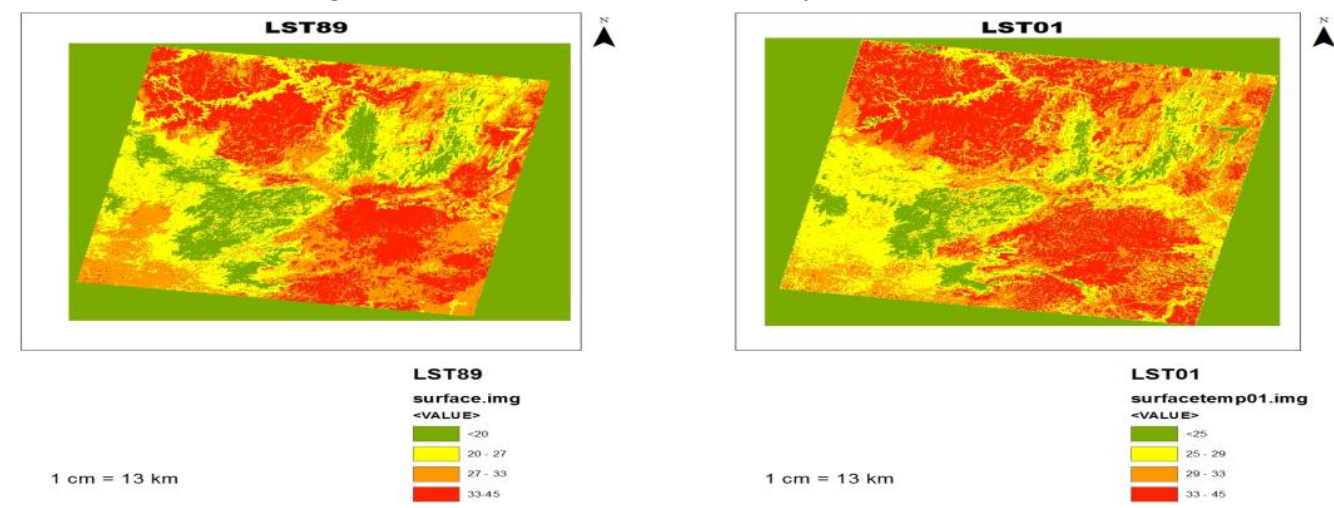

Fig No.4.26 LST variation for the year $1989 \& 2001$

The spatial distribution of LST and NDVI is shown in Fig No.4.27 \&4.28. The areas with the lowest vegetation levels were concentrated within the south eastern parts and north western portions of the study area Low NDVI values also appeared over the Cauvery River (which runs west to east through the northern portion of the study area). Conversely, high levels of NDVI indicating the presence of green vegetation were observed, primarily over the central regions of the study area. Some pockets of high NDVI were also noticeable in the north eastern and the south western portion of the study area .In general, the visual pattern of LST was opposite to that of NDVI (with the exception of the "water bodies"). Low LST readings were found mostly in the districts of Coimbatore and Erode regions of the study area. Pockets of low LSTs could also be observed within the central portion of the study area Low LSTs were also observed over the Cauvery River and around the main reservoirs (Mettur dam especially). There is a drastic change while observing the NDVI01 where the vegetation strength has gone down poorly. Whereas high NDVI observed areas in NDVI89 has gone down to some extent but the low NDVI region has no traces of vegetation. 


\section{DIFFERENCES IN LST AND NDVI}

The results indicate a significant inverse correlation between LST and NDVI for the study area. In other words, high LSTs will generally register low NDVI readings whereas low LSTs will generally register high NDVI readings. The regression functions between LST and NDVI and coefficient of determination (R2), which measures the strength of the linear regression, are shown in Fig No.4.29 and Fig No.4.30. This study has demonstrated that land surface characteristics are highly related to LSTs and will affect the general pattern of the LULC classes. Inverse relationships between LST and vegetation abundance were observed for the study area as a whole, Moreover, it was apparent through the visual interpretation of the LST and NDVI imagery that global warming was responsible for the formation of several low vegetative areas in the study area. Therefore, increasing vegetation we can preventing the basin from becoming a hotspot for UHIs. The results obtained provides the impact of climate thus by decreasing amounts of vegetation abundance mean LST values increased. With increasing NDVI, LST decreases the slowest as compared. High mean LST was found to be comparatively much more effective at reducing surface temperatures through increased vegetation.

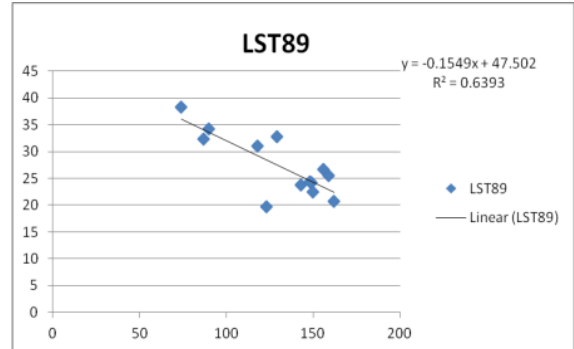

Fig No.4.27 mean lst vs mean ndvi 1989

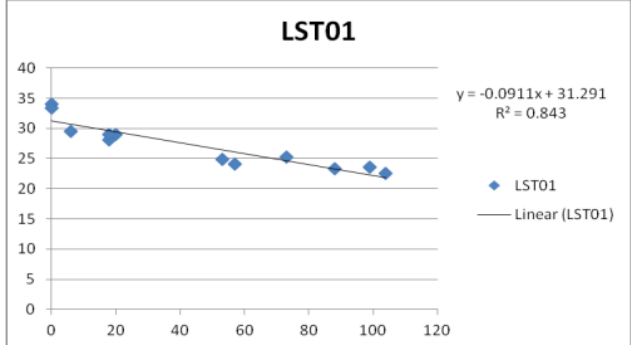

Fig No.4.28 mean lst vs mean ndvi 2001

Table no.4.5 Regressed results

\begin{tabular}{|c|c|c|}
\hline YEAR & Regression Equation & ${\text { Correlation Coefficient } \mathrm{r}^{2}}^{2}$ \\
\hline 1989 & $\mathrm{Y}=-0.1549 \mathrm{X}+47.502$ & 0.6393 \\
\hline 2001 & $\mathrm{Y}=-0.0911 \mathrm{X}+31.291$ & 0.843 \\
\hline
\end{tabular}

The table no. 4.8 shows the regressed equations of the NDVI and LST values . there exists a linear change from the year 1989 to 2001 . It shows there s a negative correlation between NDVI and LST. They inversely related due to the strong correlation among the variables where LST is independent and the NDVI is dependent. Therefore, the study clearly shows the climate change shows greater impact on land use / land cover changes.

This study is carried out to observe the land cover change which are predicted to occur due to climate change. Recognition and awareness of this functionality is critical as it can serve as a tool for adapting cities to climate change and reducing some of the negative impacts of rural and urban development through improved rural and urban planning and management strategies. LST and NDVI shared a significant inverse relationship, implying that increasing vegetation abundance will generally reduce surface temperatures

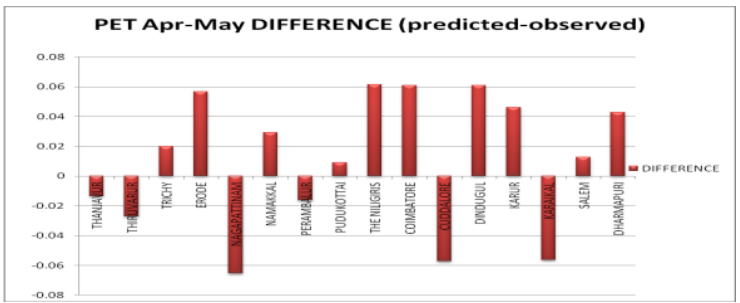

Fig No.4.29a Change in PET values for 16 stations

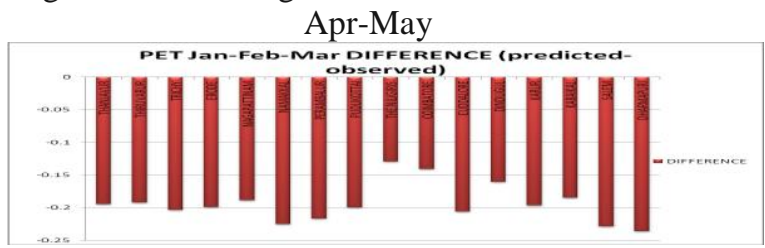

Fig No.4.29b Change in PET values for 16 stations Jan-Feb-Mar

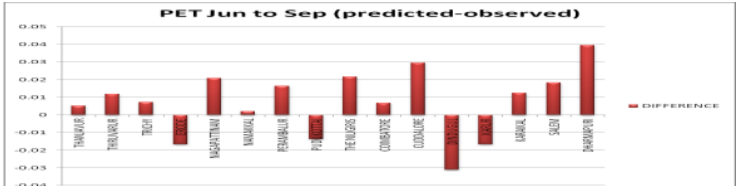

Fig No.4.29c Change in PET values for 16 stations Jun to Sep

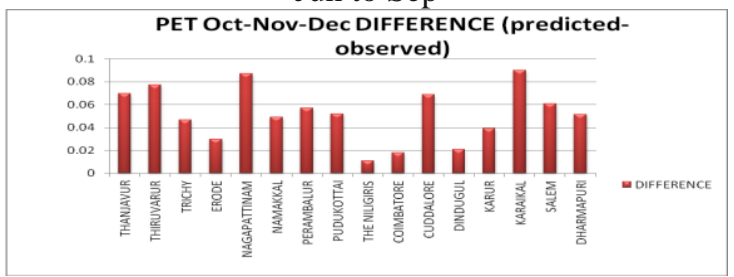

Fig No.4.29d Change in PET values for 16 stations Oct-Nov-Dec 


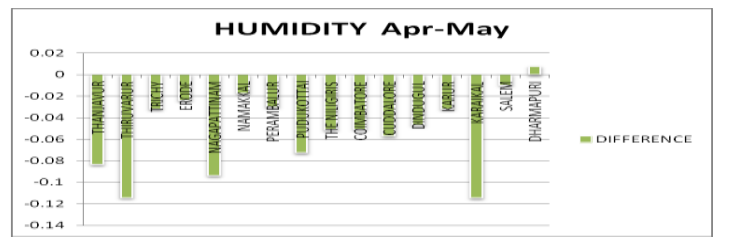

Fig No.4.30a Change in Humidity values for 16 stations Apr-May

HUMIDITYJan-Feb-Mar

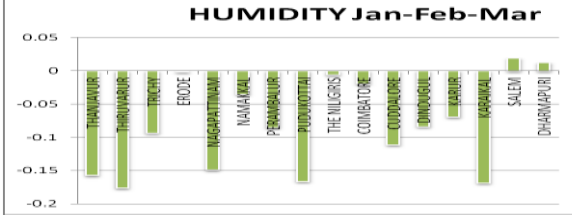

Fig No.4.30b Change in Humidity values for 16 stations Jan-Feb-Mar

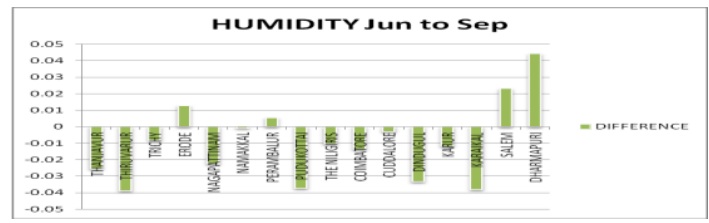

Fig No.4.30c Change in Humidity values for 16 stations Jun to Sep

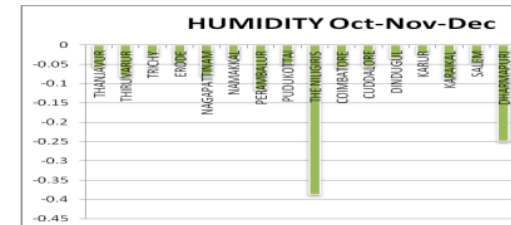

Fig No.4.30d Change in Humidity values for 16 stations Oct-Nov-Dec

Table No.4.7 Difference in humidity for all four seasons (observed - predicted)

\begin{tabular}{|c|c|c|c|c|}
\hline STATION & Jan-Feb-Mar h\% & Apr-May h\% & Jun to Sep h\% & Oct-Nov-Dec h\% \\
\hline THANJAVUR & -0.15709017 & -0.083322712 & -0.025538042 & -0.055519074 \\
\hline THIRUVARUR & -0.176102705 & -0.114097711 & -0.038866943 & -0.081971631 \\
\hline TRICHY & -0.093501147 & -0.031825305 & -0.008202137 & -0.027966405 \\
\hline ERODE & -0.001662058 & -0.023778791 & 0.012892853 & -0.045519965 \\
\hline $\begin{array}{c}\text { NAGAPATTINA } \\
\mathbf{M}\end{array}$ & -0.148726716 & -0.093642938 & -0.022656822 & -0.078328004 \\
\hline NAMAKKAL & -0.035033102 & -0.017193414 & -0.000828732 & -0.035819566 \\
\hline PERAMBALUR & -0.085148854 & -0.029891641 & 0.00548686 & -0.115610441 \\
\hline PUDUKOTTAI & -0.166153463 & -0.072586008 & -0.037267774 & -0.050730857 \\
\hline THE NILIGIRIS & -0.005923724 & -0.051303413 & -0.010444721 & -0.387275897 \\
\hline COIMBATORE & -0.019482676 & -0.050621782 & -0.013702545 & -0.057375927 \\
\hline CUDDALORE & -0.111232843 & -0.056985848 & -0.003006846 & -0.054408394 \\
\hline DINDUGUL & -0.083654494 & -0.04702699 & -0.033306119 & -0.034384469 \\
\hline KARUR & -0.069376973 & -0.032012187 & -0.01195112 & -0.022369237 \\
\hline KARAIKAL & -0.168495896 & -0.114398558 & -0.038007527 & -0.086889269 \\
\hline SALEM & 0.019112906 & -0.009601379 & 0.023244575 & -0.043205116 \\
\hline DHARMAPURI & 0.012733617 & 0.007906197 & 0.044311943 & -0.248935889 \\
\hline
\end{tabular}

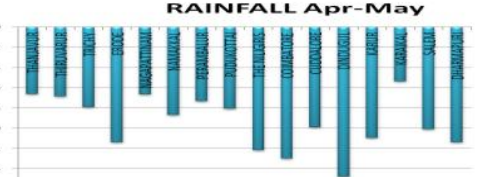

Fig No.4.31a Change in Rainfall values for 16 stations Apr-May

\section{"II"}

Fig No.4.31b Change in Rainfall values for 16 stations Jan-Feb-Mar 


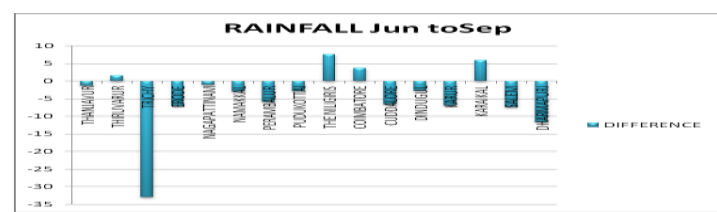

Fig No.4.31c Change in Rainfall values for 16 stations Jun to Sep

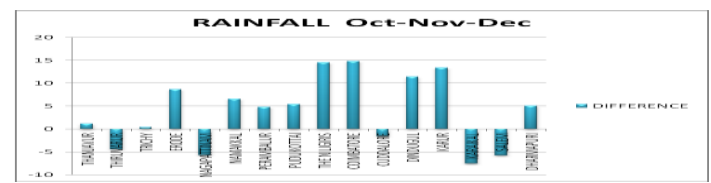

Fig No.4.31d Change in Rainfall values for 16 stations Oct-Nov-Dec

Table No. 4.8 Differences in rainfall for all four seasons (observed - predicted)

\begin{tabular}{|c|c|c|c|c|}
\hline STATION & Apr-May $\mathrm{r} \mathrm{mm}$ & Jan-Feb-Mar $\mathrm{rmm}$ & Jun to Sep r mm & Oct-Nov-Dec $\mathrm{r} m m$ \\
\hline THANJAVUR & -6.623496032 & -1.388238734 & -1.307817514 & 1.134743738 \\
\hline THIRUVARUR & -6.846015011 & -2.056396229 & 1.558485301 & -4.405887522 \\
\hline TRICHY & -7.921499988 & -2.061015428 & -32.94004896 & 0.404449985 \\
\hline ERODE & -11.39201672 & -0.988045796 & -7.067506537 & 8.592202189 \\
\hline NAGAPATTINAM & -6.661725246 & -0.602691426 & -1.083316527 & -5.68962927 \\
\hline NAMAKKAL & -8.693705354 & -3.133166684 & -2.944292251 & 6.554808906 \\
\hline PERAMBALUR & -7.304964339 & -2.013543713 & -5.876215062 & 4.743687088 \\
\hline PUDUKOTTAI & -8.062206385 & -2.072267931 & -2.855589557 & 5.346994703 \\
\hline THE NILIGIRIS & -12.16674398 & -2.662266295 & 7.498470357 & 14.50917366 \\
\hline COIMBATORE & -12.98549023 & -1.658478002 & 3.645067992 & 14.80592684 \\
\hline CUDDALORE & -9.915601592 & 1.302917091 & -6.698662039 & -1.588693137 \\
\hline DINDUGUL & -14.84024444 & -1.502202946 & -2.808378872 & 11.37739238 \\
\hline KARUR & -10.9688529 & -2.648660869 & -6.925811345 & 13.34103746 \\
\hline KARAIKAL & -5.363044305 & -1.167610384 & 5.865880286 & -7.522636162 \\
\hline SALEM & -10.0991886 & -1.939661282 & -7.37661829 & -5.78866599 \\
\hline DHARMAPURI & -11.38805961 & -1.722230036 & -11.66620418 & 5.039117937 \\
\hline
\end{tabular}

\subsection{Summer season:}

During the months of Apr-May the predicted PET from the Fig no.4.17a, 4.17b, 4.17c and 4.18 has its maximum value expected at the Dharmapuri station with the PET of $7.37 \mathrm{~mm}$ and the minimum expected PET at Karaikal station is $5.95 \mathrm{~mm}$. The station that will have an average PET of $6.46 \mathrm{~mm}$ is Trichy. And also, from Fig no. $4.29 \mathrm{a}$, and table 4.6 one can infer that there will be neither an increased nor a decreased pattern of PET. Maximum decrease will be observed at Nagapattinam with $0.062 \mathrm{~mm}$ PET and maximum increase at Niligiris with $0.062 \mathrm{~mm}$. Minimum values of PET will be seen at the Thanjavur with the decrease of $0.02 \mathrm{~mm}$ and at Pudukottai with an increase of $0.01 \mathrm{~mm}$.

\subsection{Dry season:}

During the months of January - February - March the highest predicted values will be seen from the Fig 4.19a, 4.19b, 4.19c and 4.20 at Dharmapuri with $6.645 \mathrm{~mm}$ and the minimum at the Karaikal station with $5.32 \mathrm{~mm}$. Dindugal with $5.99 \mathrm{~mm}$ stays as an average station. The inference for this season is observed from the Fig $4.29 \mathrm{~b}$ and table 4.6 is to be consistently decrease. The highest difference will be expected at Dharmapuri with decreased PET of $-0.24 \mathrm{~mm}$ and with the minimum decrease at Niligiris station with $-0.125 \mathrm{~mm}$. Thanjavur and Thiruvarur will have an average decreas of $0.193 \mathrm{~mm}$.

\subsection{South west monsoon:}

During the months of June to September has got the effects of south west winds and the predicted PET values will expected to raise the highest at Cuddalore with $6.027 \mathrm{~mm}$ and lower at Niligiris with $4.94 \mathrm{~mm}$. Thnjavur remains to be at the average with $5.57 \mathrm{~mm}$ from the Fig 4.21a, 4.21b, 4.21c and 4.22 .Inference made donot follow any consistent pattern from the Fig 4.29c and table 4.6 the highest will be expected at Dharmapuri with an increase of $0.04 \mathrm{~mm}$ and the highest decrease at Dindugal station with $0.031 \mathrm{~mm}$. The minimal values are to be occur at Namakkal with an increase of $0.002 \mathrm{~mm}$ and minimal decrease at Pudukottai with decrease of $0.014 \mathrm{~mm}$.

\subsection{North east monsoon:}

October to December falls on north east winds. In this season the highest expected PET from the Fig $4.23 \mathrm{a}, 4.23 \mathrm{~b}, 4.23 \mathrm{c}$ and 4.24 is at Dharmapuri with $5.33 \mathrm{~mm}$ and the minimum value will be at Kraikal with 4.58 
$\mathrm{mm}$. Trichy will have an average of $44.94 \mathrm{~mm}$. The inference made for this season shows that there is a consistent increase in the PET pattern at the 16 stations of Cauvery basin. The increased value is seen from the Fig $4.29 \mathrm{~d}$ and table 4.6 is at Karaikal with $0.09 \mathrm{~mm}$ and the minimum increase at Niligiris with $0.0125 \mathrm{~mm}$. Pudukottai with average increase with $0.057 \mathrm{~mm}$.

Relative humidity for all the four seasons show a consistent decrease. The following paragraphs shows the pattern for every season.

\subsection{Summer season :}

During the months of Apr-May Fig 4.9a, 4.9b, 4.9c and 4.10 shows maximum humidity at Dindugal with $74.67 \%$ whereas Dharmapuri will show a minimum \% of humidity of 61.32 . Erode stays moderate with 68.66\%.The predicted inference from Fig 4.30a and table 4.7 shows that there is a complete decrease in the humidity for the overall 16 stations. The maximum decreased value expected to be recorded at Karaikal with $0.032 \%$ and the minimum value is expected at Dharmapuri with a slight increase of $0.007 \%$.Niligiris, Coimbatore and Cuddalore will have an average decrease of $0.051 \%$.

\subsection{Dry season :}

During the months of January-February-March Fig 4.11a, 4.11b, 4.11c and 4.12 shows there is a consistent decrease in humidity. Highest record will be at Karaikal with $73.15 \%$ and the minimum at Dharmapuri $60.16 \%$. Trichy has an average value of $68.32 \%$. The difference inferred from Fig $4.30 \mathrm{~b}$ and table 4.7 is found to be decreasing with the maximum value of $-0.176 \%$ at Thiruvarur station and the minimum at Salem with $0.019 \%$. Dindugal got an average value of decrease with $0.080 \%$.

\subsection{South west monsoon:}

During the months of June to September, experiences south west winds and Fig 4.13a, 4.13b, 4.13c and 4.14 shows there is a maximum humidity that will be expected at Niligiris with $83.17 \%$ and the minimum humidity at Cuddalore with $69.018 \%$. Average humidity will be at Trichy with $75.18 \%$. The estimated difference shown in Fig 4.30c and table 4.7 is decreasing the maximum at Thiruvarur (-0.0388\%) and minimum at Namakkal (-0.0008\%).average decrease will be at Karur $(-0.011 \%)$. Three stations alone will show increase in humidity, they are: Dharmapuri(0.044\%), Salem(0.023\%), and Erode(0.01\%).

\subsection{North east monsoon:}

During the months of October to December will experience north east winds where the humidity shown in Fig 4.15a, 4.15b, 4.15c and 4.16 will be maximum at Dindugal $(80.607 \%)$ and minimum at Salem(72.39\%). Average humidity will be at Cuddalore station(76.68\%). The estimated difference shown in Fig $4.30 \mathrm{~d}$ and table 4.7 has consistent decrease with the maximum difference at Niligiris $(-0.3872 \%)$ and a minimum difference at Karur $(-.002 \%)$.

Average seen at Karaikal (-0.0891\%). Rainfall for all the 16 stations are predicted season wise and there is expected a decrease throughout the summer, dry and south west monsoon seasons and an increase in northeast monsoon season.

\subsection{Summer season:}

During the months of Apr-May the above Fig 4.1a, 4.1b, 4.1c, and 4.2 shows there will be heavy rains at Coimbatore with $135.7 \mathrm{~mm}$ and the lowest at Nagapattinam with $26.98 \mathrm{~mm}$. Namakkal, Karur, Salem, Dharmapuri will experience a moderate rainfall with approximately $60-75 \mathrm{~mm}$. The estimated differences from the Fig 4.31a and table 4.8 will be expected to have an constant decrease with the maximum decrease at Dindugal $(-14.84 \mathrm{~mm})$ and minimum decrease at Karaikal $(-5.363 \mathrm{~mm})$.Cuddalore will have a moderate decrease in rainfall of $-9.915 \mathrm{~mm}$.

\subsection{Dry season :}

During the months of January to March the Fig 4.3a, 4.3b, 4.3c and 4.4 shows highest rainfall expected at Dindugal with $15.58 \mathrm{~mm}$ and the lowest at Dharmapuri with $3.19 \mathrm{~mm}$. Erode, Thanjavur, Trichy, Karur, Pudukottai will experience a moderate rainfall with approximately 7 to $9 \mathrm{~mm}$. The estimated difference from the Fig $4.31 \mathrm{~b}$ and table 4.8 has a constant decrease in all the 15 stations and one station has an increase of $1.30 \mathrm{~mm}$ rainfall at Cuddalore. The highest decrease will be at Namakkal with $-3.13 \mathrm{~mm}$ and the lowest decrease at Nagapattinam with $-0.602 \mathrm{~mm}$. Coimbatore will have a moderate decrease at Coimbatore with $-1.658 \mathrm{~mm}$.

\subsection{Southwest monsoon :}

During the months of June to September the Fig 4.5a, 4.5b, 4.5c and 4.6 maximum rainfall is to be recorded at Niligiris with $456.44 \mathrm{~mm}$ and the minimum rainfall is to be at Trichy with $60.99 \mathrm{~mm}$. Erode, Karur, Dindugal will have moderate rainfall with approximately 110 to $190 \mathrm{~mm}$. The estimated differences shown in 
Fig $4.31 \mathrm{c}$ and table 4.8 there is a neither increase nor decrease pattern to be observed. They are partly decreasing and increasing at four stations. The maximum increase is to be seen at Niligiris with $7.498 \mathrm{~mm}$ of rainfall and the minimum increase at Thiruvarur with $1.558 \mathrm{~mm}$. The maximum decrease will be at Trichy with $-32.94 \mathrm{~mm}$ and the minimum decrease of $-1.08 \mathrm{~mm}$ will be at Nagapattinam. The moderate decrease is to be at Perambalur with $-5.87 \mathrm{~mm}$.

\subsection{North east monsoon:}

During the months of October to December Fig 4.7a, 4.7b, 4.7c and 4.8 shows the rainfall is maximum at Karaikal with $216.19 \mathrm{~mm}$ and the minimum is at Dharmapuri with $88.098 \mathrm{~mm}$. Niligiris, Karur, Coimbatore and Dindugal will experience a moderate rainfall of approximately 130 to $145 \mathrm{~mm}$. The estimated changes observed from Fig 4.31d and table 4.8 shows a partly increasing nature of rainfall and in four stations there is a decrease. The maximum increase in rainfall is to be seen in Coimbatore with $14.805 \mathrm{~mm}$ and minimum increase at Trichy with $0.404 \mathrm{~mm}$. The maximum decrease will be likely to occur at Karaikal with $-7.52 \mathrm{~mm}$ and the minimum decrease at Cuddalore with $-1.588 \mathrm{~mm}$. Average increase is to be seen at Perambalur with $4.74 \mathrm{~mm}$. One can observe there is a overll decrease in the relative humidity and rainfall but there is a varied pattern in the PET due to climate change after 2021.

\section{CONCLUSION}

The following conclusions are drawn from the study. When predicting the PET for future the following is concluded stating that Dry season will show a consistent decrease, Summer season will show neither increase nor decrease, South west monsoon will show neither increase nor decrease and North east monsoon will show a consistent increase. One can observe there is an overall decrease in the relative humidity and rainfall but there is a varied pattern observed in the PET due to climate change. It is estimated that there is an overall decrease of $20 \%$ in the humidity and rainfall pattern and the change in PET is 5\% increased and $10 \%$ decreased according to the season wise change in each station. There is a negative correlation between the two natural factors. Therefore, one can see there is a decrease in vegetation due to increase in temperature and for every geographic cycle there is decrease in vegetation and the climate pattern differs.

\section{REFERENCES}

[1]. Abduwasit Ghulam, PhD. (2010), ' Calculating surface temperature using Landsat thermal imagery', Student handout-Center for Environmental Sciences Saint Louis University Thesis nr29.

[2]. Andrew Farina (2012), 'Exploring the relationship between land surface temperature and vegetation abundance for urban heat island mitigation in Seville, Spain', LUMA-GIS Thesis nr 15.

[3]. Artis, D.A., and Carnahan, W.H., (1982) 'Survey of Emissivity Variability in Thermography of Urban Areas'. Remote Sensing of Environment, Vol No 12, pp313-329.

[4]. Arun Kumar and Th.Nixon Singh 2012, 'Predicting future changes in climate of micro watershed from statistical relationships among climatic variable Indian society of geomatics', Journal of Geomatics, Vol 6 No.1 April 2012

[5]. Bard.B(1994), 'Bio sphere aspects of the Hydrological cycle (BAHC) focus 4', the weather generator project. HABC report no4, 2-12

[6]. Coll, J. M. Galve, J. M. Sánchez, and V. Caselles, 'Validation of Landsat-7/ETM+ Thermal-Band Calibration and Atmospheric Correction with Ground-Based Measurements', IEEE Trans. Geosci. Remote Sens., vol. 48, no. 1, pp. 547-555, Jan.

[7]. Elizabeth E. Holmes, Eric J. Ward, Kellie Wills 2012, MARSS: Multivariate Autoregressive State-space Models for Analyzing Time-series Data R journal 2012

[8]. Enslein,K.,Ralston,A.\& Wilf,H.S(1997) Statistical methods for Digital Computers, Wiley, Newyork,USA

[9] Gokilarani.G (2010), 'Spatial dynamic modelling for land use / landcover change 2010' Anna University Thesis work.

[10] Hashino,M.\& Yue .S.(1994), 'Statistical analysis of effects of monthly temperature on monthly precipitation properties' In: Proc. Second symposium on Earth Environment(Tokyo),pp207-212. JSCE 